\title{
PEMERIKSAAN RADIOLOGI PADA KASUS \\ HIPERTROPHY PYLORIC STENOSIS (HPS)
}

\author{
Fauzy Ma'ruf \\ Fakultas Kedokteran Universitas Islam Al-Azhar \\ J1. Unizar No.20 Turida Mataram \\ Email: fauzyma69ruf@gmail.com
}

\begin{abstract}
ABSTRAK
Hipertropi pyloric stenosis (HPS) merupakan gangguan gastrointestinal paling sering pada bayi. Pada HPS terjadi penebalan muskulus sirkuler antropyrolus dan menyebabkan konstriksi serta obstruksi di gastric outlet.

Pemeriksaan dengan barium merupakan pemeriksaan penting untuk deteksi HPS. Selain itu USG juga digunakan sebagai pilihan prosedur diagnostik HPS karena tekniknya cepat dan relatif mudah dilakukan. Sensitivitas dan spesifitas pemeriksaan USG bisa mencapai $89 \%$ sampai $100 \%$ dan akurasinya bisa sampai100\%. Hal ini merupakan alasan mengapa USG digunakan secara luas.
\end{abstract}

Kata Kunci : HPS, Barium, USG

\section{PENDAHULUAN}

Hipertropi Pyloric Stenosis (HPS) merupakan suatu kondisi yang terjadi pada bayi dengan lambung bagian pylorus mengalami penebalan yang abnormal. Definisi lainnya, HPS merupakan kelaina penyempitan di jalan keluar lambung sampai bagian pertama dari duodenum disebabkan hipertrophy muskulus sekitar jalan keluar tersebut (pilorus) dan mengalami spasme saat lambung kosong.

\section{Anatomi Lambung}

Lambung merupakan organ berbentuk kantong seperti huruf ' $J$ ', dengan volume pada orang dewasa 12001500cc pada saat berdilatasi. Sedang lambung bayi baru lahir mempunyai kapasitas 10-20cc, bayi usia satu minggu 30-90cc, bayi usia dua sampai tiga minggu 75-100cc, bayi usia satu bulan 90-150cc, bayi usia tiga bulan 90-150cc, dan bayi usia satu tahun 210-360cc. Pada bagian superior, lambung berbatasan dengan bagian distal esofagus, sedangkan bagian inferior berbatasan dengan duodenum. Lambung terletak pada daerah epigastrium dan meluas ke hipochondrium kiri. Kecembungan lambung yang meluas ke gastroesofageal junction disebut curvatura mayor. Kelengkungan lambung bagian kanan disebut curvatura minor, dengan ukuran $1 / 4$ dari panjang curvatura mayor. Seluruh organ lambung terdapat di dalam rongga peritoneum dan ditutupi oleh omentum.

Secara anatomi lambung terbagi atas 5 daerah yaitu: (1) Cardia, daerah yang kecil terdapat pada bagian superior di dekat gastroesofageal junction; (2) Fundus, bagian berbentuk kubah yang berlokasi pada bagian kiri dari kardia dan meluas ke superior melebihi tinggi gastroesofageal junction; (3) Corpus, merupakan $2 / 3$ bagian dari lambung dan berada di bawah fundus sampai ke bagian 
paling bawah yang melengkung ke kanan membentuk huruf 'J' (4) Antrum pilori, adalah bagian $1 / 3$ bagian distal dari lambung. Keberadaannya secara horizontal meluas dari korpus hingga ke sphincter pilori (5) Sphincter pilori, merupakan bagian tubulus yang paling distal dari lambung. Bagian ini secara keseluruhan dikelilingi oleh lapisan otot yang tebal dan berfungsi mengontrol lewatnya makanan ke duodenum. Permukaan fundus dan korpus banyak dijumpai lipatan (rugae) lambung. Pembuluh darah yang mensuplai lambung merupakan percabangan dari arteri celiac, hepatik dan splenik. Aliran pembuluh vena lambung dapat secara langsung masuk ke sistem portal atau secara tidak langsung melalui vena splenik dan vena mesenterika superior. Nervus vagus mensuplai persyarafan parasimpatik ke lambung dan pleksus celiac merupakan inervasi simpatik. Banyak ditemukan pleksus saluran limfatik dan kelenjar getah bening lainnya.

Dinding lambung terdiri dari empat lapisan yaitu lapisan mukosa, submukosa, muskularis eksterna (propria) dan serosa. Permukaan mukosa dilapisi oleh sel epitel kolumnar penghasil mukus dan meluas ke sebagian foveolar atau pit. Lapisan mukosa terbagi atas dua lapisan yaitu lamina propria dan lapisan muskularis mukosa. Pada lapisan muskularis mukosa, terdapat lapisan otot sirkuler pada bagian dalam dan lapisan otot longitudinal pada bagian luarnya. Otot-otot ini berkelanjutan membentuk kelompokan kecil (fascia) otot polos yang tipis menuju ke bagian dalam lamina propria hingga ke permukaan epitel. Pada lapisan submukosa, jaringannya longgar dan mengandung sejumlah jaringan ikat elastik, terdapat pleksus arteri, vena, pembuluh limfe dan pleksus nervus Meissner. Muskularis eksterna terdiri dari tiga lapisan yaitu longitudinal luar (outer longitudinal), sirkuler dalam (inner sirkuler) dan oblik yang paling dalam (innermost oblique). Lapisan sirkuler sphincter pilorik pada gastroesofageal junction. Pleksus Auerbach (myenteric) berlokasi pada daerah di antara lapisan sirkular dan longitudinal dari muskularis eksterna.

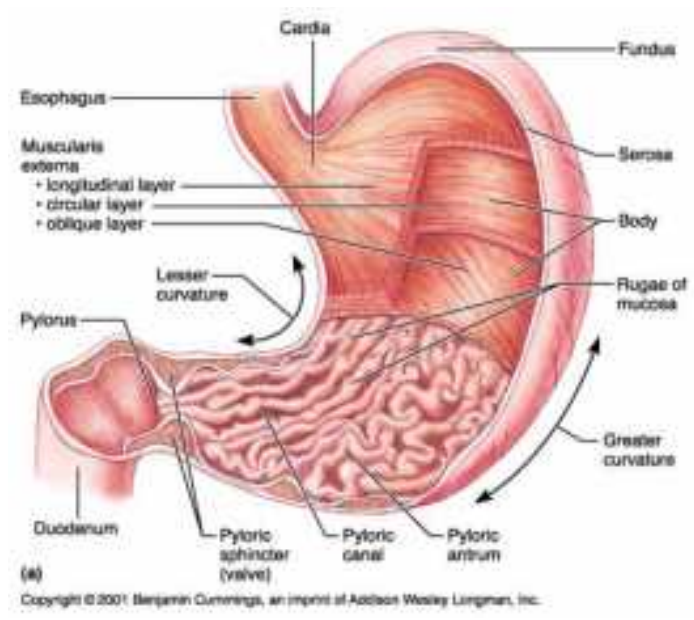

Gambar 1.1 Anatomi Lambung

\section{Epidemiologi}

HPS sering terjadi pada bayi dengan usia kehidupan 2-10 minggu. Insidensinya di populasi barat 2-4 per 
1000 bayi lahir hidup tetapi pada populasi Asia dan Afrika lebih rendah. Bayi lakilaki lebih banyak terkena daripada perempuan dengan perbandingan 4:1. Alasan kenapa lebih banyak pada lakilaki tidak diketahui. Terdapat beberapa kasus kejadian HPS meningkat pada kelahiran anak pertama dan $7 \%$ terjadi pada keluarga yang mempunyai riwayat serupa. HPS lebih sering terjadi pada bayi yang mendapatkan minum dari botol pada populasi pedesaan. Resiko yang rendah terjadi pada umur ibu yang lebih tua, pendidikan ibu yang tinggi, dan berat badan lahir rendah.

\section{Gejala Klinis}

Manifestasi klinis HPS adalah obstruksi yang menyebabkan muntah proyektil non bilous sesudah pemberian minuman formula atau ASI. Muntah yang terus menerus menyebabkan terjadinya pengosongan lambung. Tampak peristaltic lambung dan teraba masa di perut yang bentuk olive di kuadran kanan atas. Frekuensi dan volume muntah sering kuat dan berkepanjangan, sehingga produk muntah bisa berupa darah kebiruan karena gastritis. Pada suatu penelitian, $66 \%$ pasien disertai hematemesis karena esofagitis atau gastritis. Tergantung berapa lama gejala terjadi, sebagian pasien mengalami dehidrasi, alkalosis, hipokalemia, irritable, berat badan turun, dan pertumbuhan lambat. Keadaan jaundice terjadi pada kira-kira $2 \%$ bayi dengan HPS sekunder. Tujuh persen berhubungan dengan malformasi. Tiga malformasi utama yaitu malformasi intestinal, obsruksi uropati dan atresia esofagus. Selain itu anomali lain yang berhubungan dengan stenosis pilorus antara lain hiatal hernia, gangguan aktifitas hepatic glucovenyl transferase (sindrom Gilbert).

\section{Etiologi}

Etiologi HPS sampai saat ini belum diketahui. HPS bisa merupakan kejadian kongenital maupun didapat. Teori yang menjelaskan etiologi ini antara lain hiperaktifitas lambung yang menyebabkan spasme, hipertropi muskulus dan inervasi pilorus yang abnormal. Adanya predisposisi genetik disertai faktor lingkungan merupakan penjelasan yang paling banyak diterima. Abnormalitas kromosom yang dilaporkan antara lain adanya translokasi kromosom 8 dan 17 serta trisomi sebagian dari kromosom 9. Kontribusi genetik didukung oleh suatu fakta 19\% laki-laki dan $7 \%$ perempuan dengan ibu yang mengalami stenosis pilorus. Stenosis pilorus terjadi hanya pada 5\% laki-laki dan $2,5 \%$ perempuan dengan ayah yang mempunyai penyakit serupa.

\section{Patogenesis}

Meskipun HPS pada bayi adalah 
kondisi paling umum yang membutuhkan pembedahan dalam beberapa bulan pertama kehidupan, namun patogenesisnya tidak sepenuhnya dipahami. Perkembangan terbaru patogenesis HPS pada bayi antara lain: (1) Adanya bukti menunjukkan sel-sel otot polos di HPS pada bayi tidak mempunyai inervasi yang baik (2) Karena saraf non-adrenergik, non-kolinergik merupakan mediator relaksasi otot halus, sehingga terdapat kemungkinan tidak adanya saraf ini di otot pilorus menyebabkan kontraksi berlebihan dan terjadi hipertrofik otot pylorus sirkuler (3) Terdapat sejumlah protein matriks ekstraseluler yang abnormal dalam otot pilorus hipertrofik. Sel otot sirkuler pada HPS secara aktif mensintesis kolagen dan hal ini bertanggung jawab tehadap karakter dari tumor pilorus (4) Peningkatan ekspresi insulin-like growth factor-I, transforming growth factor- beta 1, dan platelet derived growth factor- $B B$ dan reseptor otot hipertrofik pilorus menunjukkan peningkatan sintesis lokal dari faktor pertumbuhan dan mungkin memainkan peran penting dalam hipertrofi otot polos HPS.

\section{Diagnosis}

Untuk menegakkan diagnosis HPS

$\begin{array}{lcr}\text { diperlukan } & \text { pemeriksaan } & \text { fisik, } \\ \text { pemeriksaan } & \text { laboratorium, dan } \\ \text { pemeriksaan } & \text { penunjang. Pemeriksaan }\end{array}$

penunjang meliputi pemeriksaan gastrointestinal dengan kontras dan pemeriksaan USG.

\section{Pemeriksaan fisik}

Pada pemeriksaan klinis didapatkan gambaran yang bervariasi. Bayi datang ke klinisi bisa masih dalam hidrasi baik maupun sudah mengalami dehidrasi berat. Namun bayi sering datang dengan tanda dehidrasi dengan berat badan rendah dan nafsu makan yang tak terpuaskan sehingga tampak kening muka berkerut dan keriput. Pada beberapa bayi, didapatkan perut buncit di hipokondrium, dan tampak aktivitas peristaltik meningkat di dinding perut yang tipis. Pada palpasi tampak massa bentuk bulat telur, mobile, yang teraba di epigastrium atau di kuadran kanan dan disebut sebagai olive sign (gambar 2). Tanda tersebut diaggap menjadi hallmark diagnostic HPS. Pada beberapa penelitian $70 \%$ pasien HPS mempunyai tanda olive sign (+) dan dengan gelombang peristaltik yang meningkat. Namun sensitivitas temuan olive sign pada HPS sekitar 75\%$85 \%$. 


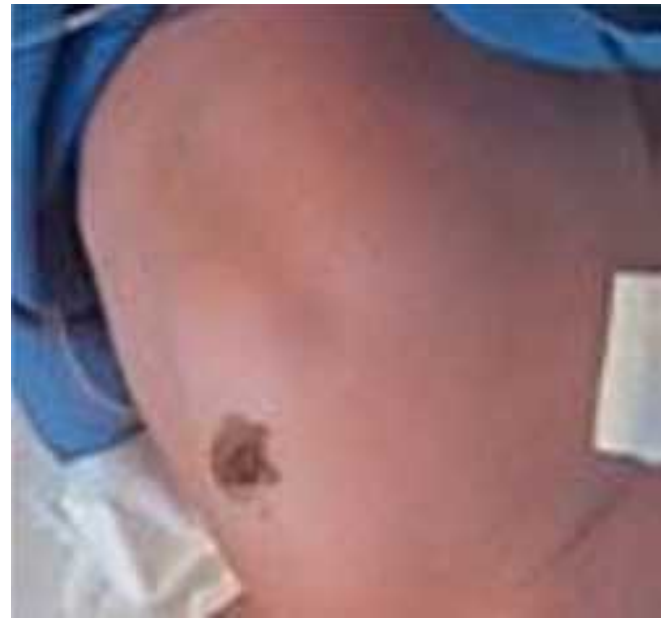

Gambar 2.1 Olive sign dengan gelombang peristaltic.

\section{Foto Polos Radiografi}

Foto polos radiografi tidak mempunyai peran penting dalam penentuan diagnosis HPS. Distensi lambung masif (diameter $>7 \mathrm{~cm}$ ) dengan isi cairan atau udara dengan gambaran gas di intestinal minimal yang disebut sebagai single bubble (gambar 3) umumnya mendukung diagnosis HPS. Namun temuan tersebut tidak spesifik. Karena jika sebelum dilakukan foto polos pasien muntah, sehingga lambung tampak tidak terlalu distensi. Selain itu tampak gambaran caterpillar sign yang merupakan tanda peningkatan gelombang peristaltik di gaster.

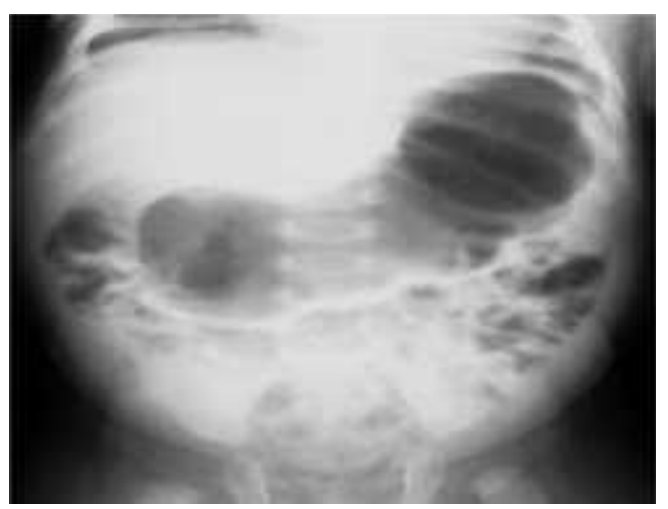

Gambar 3.1 Distensi gaster masif (single bubble) dengan gambaran udara usus minimal di distal)

\section{Pemeriksaan Ultrasonografi}

USG menjadi modalitas pilihan untuk diagnosis HPS. Selain sensitifitas dan spesifitas yang tinggi, USG bebas dari radiasi dan dapat mengikuti visualisasi dari muskulus pilorus secara langsung. Pemeriksaan menggunakan transduser linear 5-7,5 MHz. Transduser sampai $10 \mathrm{MHz}$ dapat digunakan tergantung ukuran bayi dan dalamnya pilorus.

Anatomi normal lambung pada pemeriksaan USG (gambar 4), pada potongan longitudinal dengan meletakkan probe sedikit ke kanan dari midline tampak bull's eye appearance dari antrum lambung yang letaknya di anterior pankreas dan vena mesenterika superior. Pada potongan melintang gambaran bull's eye dari antropilorus terdiri atas: a) gambaran pencil thin yang sulit diukur, dengan tepi luar anekoik menggambarkan adanya lingkaran normal. b) permukaan dalam yang echogenic menggambarkan mukosa dan submukosa, dan c) pusat yang paling dalam berupa anechoic (gambaran cairan di saluran). Scan yang terbaik dan termudah untuk mengevaluasi antropilorus normal adalah posisi longitudinal.

Gambaran klasik sonografi HPS adalah lingkaran hipoekoik muskulus 
pylorus yang hipertropi yang mengelilingi mukosa yang ekogen di tengahnya pada potongan melintang dan disebut sebagai doughnut sign atau bull's eye atau target sign (gambar 5). Muskulus biasanya tampak hipoekoik tetapi kadang-kadang membentuk pola yang tidak seragam. Tampak muskulus lebih ekoik di banding area dekatnya namun kurang ekoik di sisi yang lain. Hal itu disebabkan efek anisotropik yang berhubungan dengan tranduser USG dan serabut silindris muskulus pilorus. Pada potongan longitudinal muskulus silindris relatif lebih hipoekoik dibanding hepar. Diameter pilorus pada potongan melintang (meliputi lumen dan kedua dinding pilorus) jarang di ukur. Panjang saluran pilorus (struktur ekogenik) dapat diukur namun lebih pendek dibanding panjang muskulus pilorus (struktur hipoekoik). Terdapat beberapa perbedaan kriteria indeks ukuran sebagai indikator HPS. Menurut Dahnert dalam Radiol Oncol 2001 oleh Frkovic $M$ et al menyebutkan kriteria HPS jika tebal muskulus pilorus $\geq 3 \mathrm{~mm}$ pada potongan melintang, diameter pilorus potongan transversal $\geq 13 \mathrm{~mm}$ dan panjang saluran pilorus $\geq 17 \mathrm{~mm}$. Sedang kriteria HPS pada USG menurut al-alawee MS et al. adalah: a) adanya penebalan muskulus pilorus pada potongan melintang dan longitudinal 4-7 mm, b) adanya saluran pilorus yang mengalami elongasi (lebih dari $14 \mathrm{~mm}$ ) atau disebut sebagai cervix sign (gambar 6), dan c) adanya obstruksi gastric outlet (misalnya saluran pilorus tidak pernah membuka secara normal). Batas ini lebih rendah pada bayi umur kurang dari 30 hari. Menurut Chan et al, pada bayi kurang dari 21 hari menggunakan 'cut off' tebal muskulus pylorus 3,5 mm.

Gambaran cervix sign disebabkan karena indentasi massa muskulus di antrum yang terisi oleh cairan pada potongan longitudinal. Gambaran antral nipple sign (gambar 7) yang merupakan gambaran mukosa saluran pilorus yang redundant dan mengalami protusio masuk kedalam antrum lambung. Diagnosis HPS dengan USG mempunyai spesifitas dan sensitifitas yang tinggi (96\% dan 100\%) serta positive predictive value lebih besar dari $90 \%$.

Saat relaksasi sering HPS pada bayi sulit dibedakan dengan pilorospasme. Pilorospasme di hipotesakan sebagai suatu stadium awal dari HPS, tetapi hal itu belum terbukti.

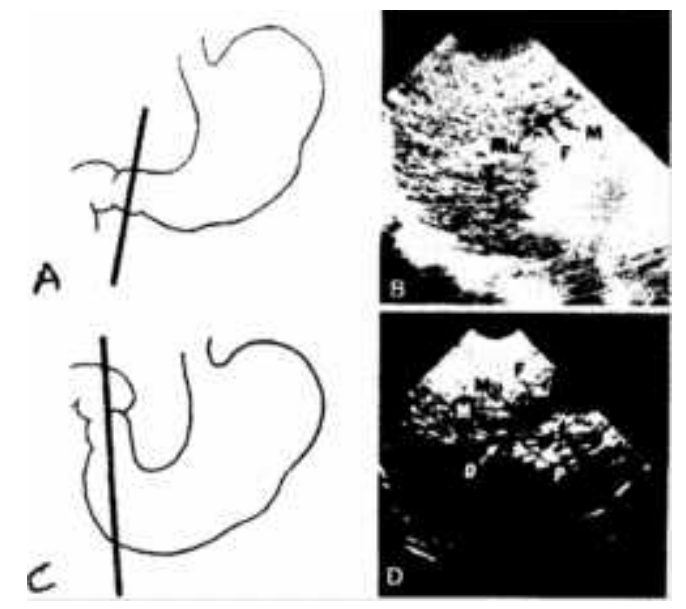


Gambar 4.1a. Anatomi normal antral gaster. $\mathrm{A}$ dan $\mathrm{C}$ : diagram yang menunjukkan ilustrasi sonografi di $\mathrm{B}$ dan D. B merupakan potongan transversal/ melintang dan D adalah potongan longitudinal. (M) permukaan muskulus, $(\mathrm{Mu})$ adalah sub mukosa dan (F) adalah cairan di dalam saluran, cairan didalam duodenum (D) (THE IRAQI POSTEGRADUATE MEDICAL JOURNAL)

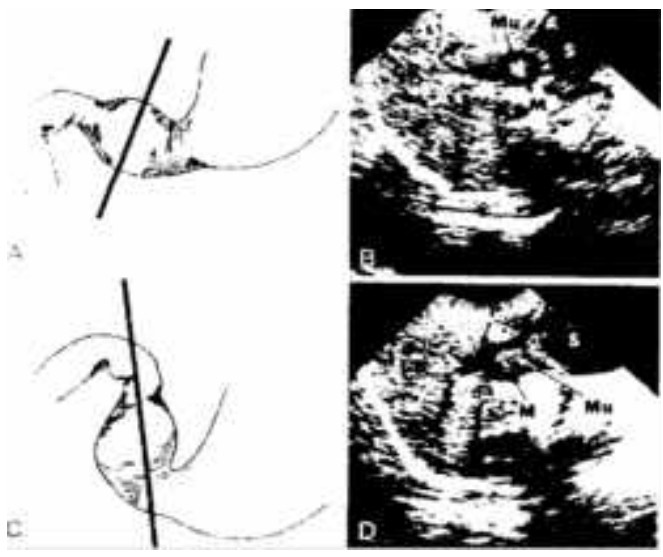

Gambar 4.2b. HPS. A dan C merupakan diagram yang merepresentasikan B dan D. B potongan transversal dan D potongan longitudinal. $\mathrm{M}$ adalah mukosa, Mu adalah sub mukosa. GB = gall bladder, $\mathrm{P}=$ saluran pylorus, $\mathrm{S}=$ stomach.

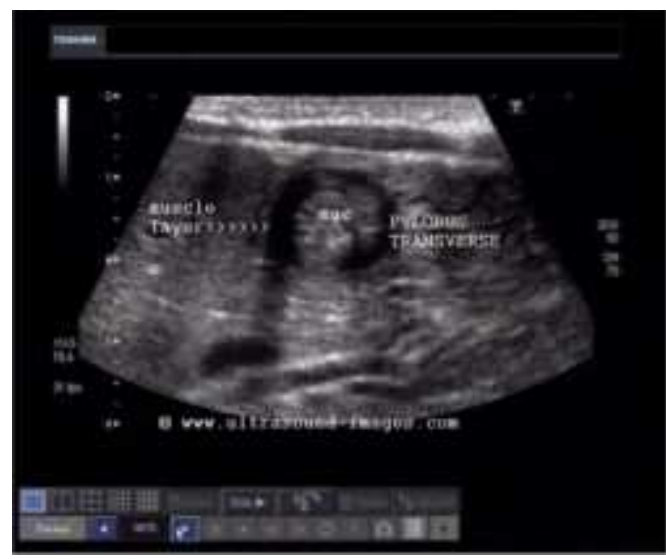

Gambar 5.1. Pilorus menunjukkan target sign atau doughnut sign pada HPS. Tanda ini merepresentasikan mukosa yang ekogenik dalam pylorus yang dikelilingi penebalan dinding muskulus yang hipoekoik.

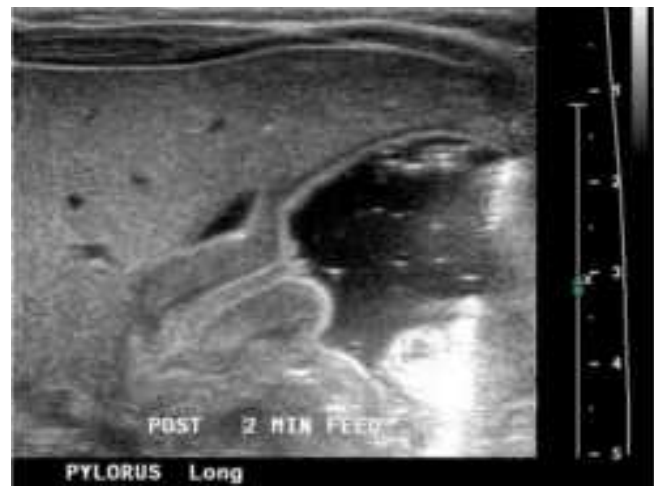

Gambar 6.1. Cervix sign pada HPS Menggambarkan indentasi pylorus masuk ke antrum yang terisi cairan.

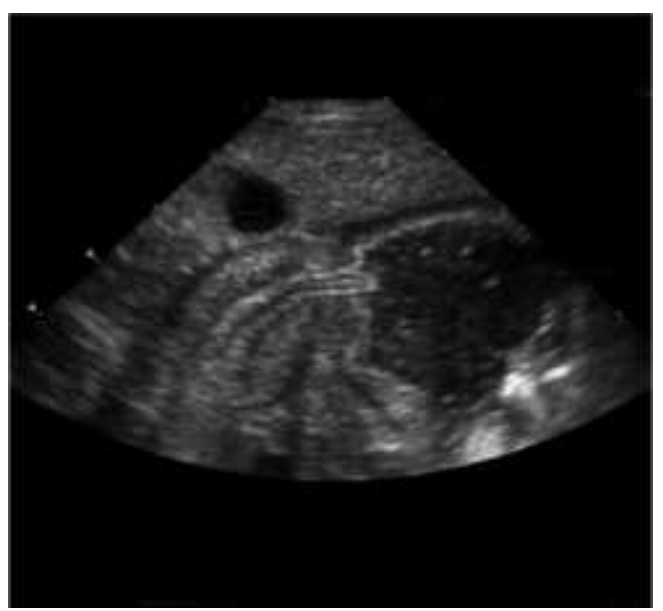

Gambar 7.1. Antral nipple sign pada HPS Menunjukkan adanya redundant mukosa pyloric yang mengalami protusio masuk ke antrum gaster.

\section{Pemeriksaan Gastrointestinal bagian}

\section{atas (Upper Gastrointestinal/UGI)}

\section{dengan Kontras}

Sebelum sonografi popular digunakan, pemeriksaan UGI dengan kontras menjadi andalan diagnosis gangguan Gastric Outlet Obstruction selama bertahun tahun. Pemeriksaan UGI dengan kontras pada HPS menunjukkan tanda tidak langsung berupa adanya efek pilorus pada lumen. Pada kasus-kasus yang meragukan pada pemeriksaan USG diperlukan pemeriksaan UGI dengan 
kontras untuk memastikan diagnosis. Selama pemeriksaan UGI dengan kontras lambung harus dikosongkan melalui selang naso gastric tube (NGT) sebelum dan sesudah dilakukan pemeriksaan agar tidak terjadi refluks dari isi lambung.

Kriteria primer diagnosis HPS pada pemeriksaan UGI dengan kontras adalah adanya penyempitan saluran pilorus, elongasi saluran pilorus dengan efek massa pilorus ke lambung dan duodenum. Bahan kontras yang melalui saluran pylorus menyebabkan lumen kanal terurai, pada beberapa kasus bahan kontras terlihat melalui lebih dari satu saluran dengan lipatan mukosa, yang dikenal sebagai double atau triple track sign (gambar 8). Gambaran lain yang ditemukan adalah string sign yang disebabkan karena penyempitan saluran pilorus menyebabkan kontras yang lewat hanya sedikit dan shoulder sign yang disebabkan karena adanya efek massa dari pilorus yang mengalami hipertropi pada antrum (gambar 9 dan 10). Gambaran teat sign merupakan puncak dari kontras di sisi curvatura minor antrum akibat adanya peristaltik sedang gambaran beak sign merupakan gambaran puncak kontras yang masuk ke dalam saluran pylorus yang menyempit. Dasar dari bulbus terindentasi oleh penebalan muskulus pilorus menimbulkan gambaran mushroom sign atau umbrella sign (gambar 11). Temuan tambahan yang lain adalah adanya hiperperistaltik lambung (caterpillar sign), volume residu lambung yang besar dan pengosongan lambung yang terlambat. Namun pengosongan lambung yang terlambat bukan indikator HPS karena dapat terjadi pada kasus pylorospasme, hipotonia lambung, sepsis dan ileus.

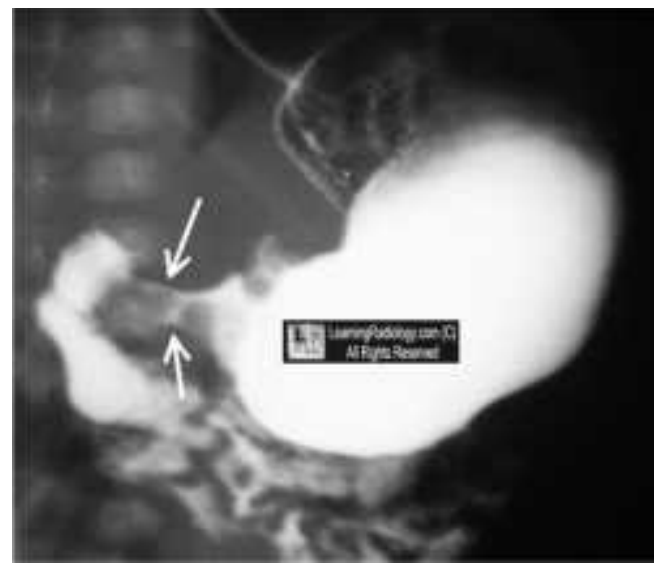

Gambar 8.1. Double track sign pada HPS

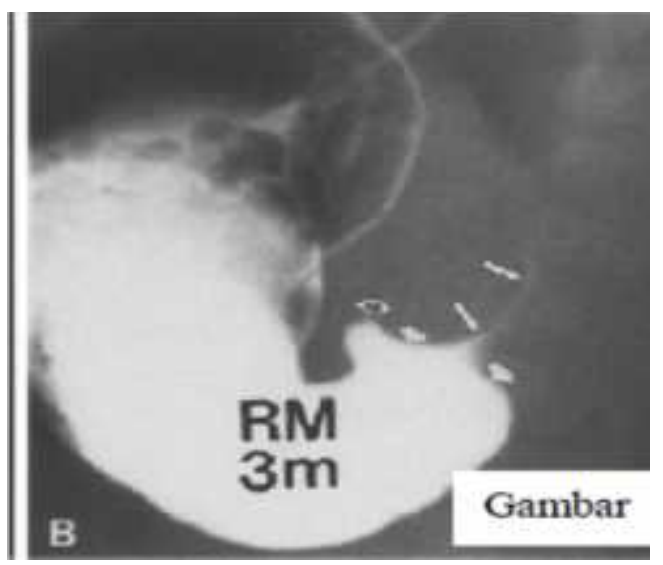

Gambar 9.1. Penyempitan pylorus (panah) dengan shoulder sign prominen (kepala panah tertutup) dan pengosongan lambung yang terlambat pada pasien1 bulan dgn stenosis pylorus. 


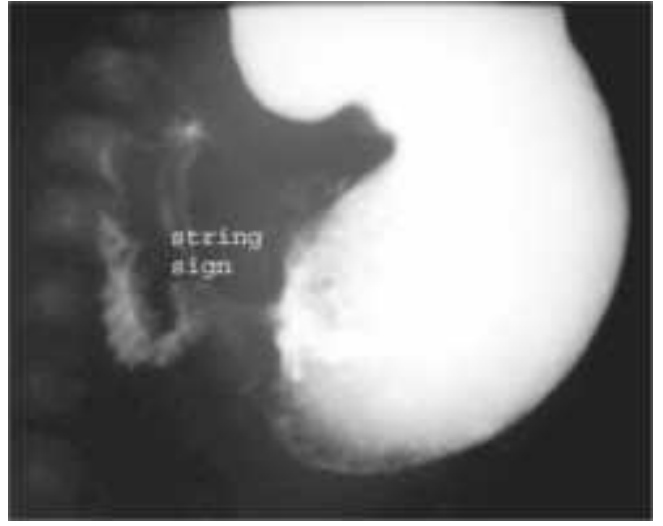

Gambar 10.1. Pemeriksaan UGI menunjukkan adanya obstruksi pylorus dengan string sign . Temuan ini konsisten dengan stenosis pylorus.

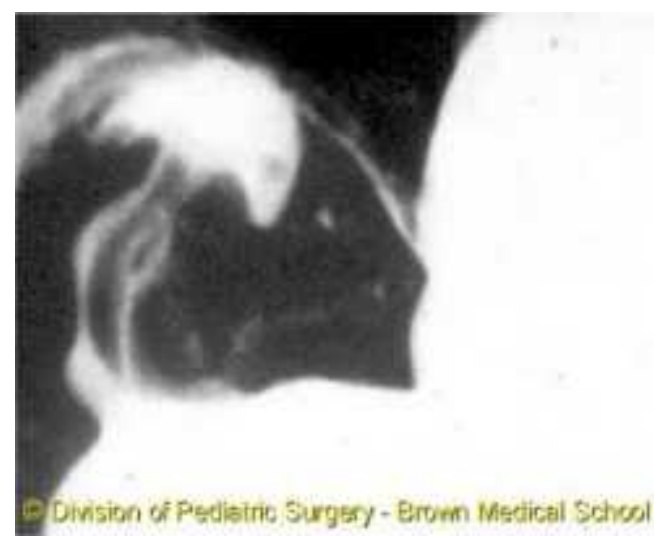

Gambar 11.1. Mushroom sign /umbrella sign pada stenosis pylorus

\section{DAFTAR PUSTAKA}

Aspelund G, Jacob C, Langer. Current management of hypertrophic pyloric stenosis. Seminars in pediatric surgery. 2007; 16: 27-33 Anonim. Wikipedia: The free encyclopedia. Available from http://en.wikipedia org/wiki/ Hypertrophic pyloric stenosis.

Al-alawee MS, Zangana AF, Almishhadany SS. The role of ultrasonography in infantile hypertrophied pyloric stenosis. The iraqi postgraduate medical journal. 2006; 5(1): 1-6

Chirdan LB, Ameh EA, Thomas AH. Infantile hypertrophic pyloric stenosis. J Pediatr Surg; 2008: 43: 1227-29

Croteau L, Arkovitz M, Berlin R, Josephs M, Kotagal U, Reeves S, et al. Hypertrophic pyloric stenosis: evidence based clinical practice guideline for hypertrophic pyloric stenosis. Children's Hospital Medical Center Cincinnati.2007.

Dias SC, Swinson S, Torrao H, Goncalves L, Kurochka S, Vaz CP, et al. Hypertrophic pyloric stenosis: tip and trick for ultrasound diagnosis. Insight imaging. 2012; 3: $247-50$

Farkovi M, Kuhar MA, Perho E, Babi VB, Molnar M, Vukovi J. Diagnostic imaging of hypertrophic pyloric stenosis (HPS). Radiol Oncol. 2001; 35(1): 11-6

Godbole P, Sprigg A, Dickson JAS, Lin PC. Ultrasound compared with clinical examination in infantile hypertrophic pyloric stenosis. Arch Dis Child 1996; 75: 335-37

Humphries JA, Steele A. Diagnosing infantile hypertrophic ploric stenosis. Clinical review. 2012; 22(9): 10, 12-15 Keet AD. Pylorospasm: The pyloric sphincteric cylinder in health and disease. 1998; 20; 89. Available from http://med.plig.org/19/88.html

Ohshiro K, Puri P. Pathogenesis of infantile hypertrophic pyloric stenosis: recent progress. Pediatr Surg Int. April, 1998; 13(4): 24352

Rogers IM. New insights on the pathogenesis of pyloric stenosis of infancy: A review with emphasis on the hyperacidity theory. Open Journal of Pediatrics 2012; 97-105 